\title{
Differential Spatial and Temporal Gene Expression in Response to Axotomy and Deafferentation following Transection of the Medial Forebrain Bundle
}

\author{
Michael Weiser, Harriet Baker, Thomas C. Wessel, and Tong H. Joh \\ Cornell University Medical College at the W. M. Burke Medical Research Institute, White Plains, New York 10605
}

\begin{abstract}
Alterations in the levels of neurotransmitter biosynthetic enzymes are a concomitant of many neurodegenerative disorders. In order to elucidate potential mechanisms for longterm alterations in biosynthetic enzyme gene products in response to neuronal injury, an acute axotomy/deafferentation model was employed. A unilateral microknife transection of the medial forebrain bundle (MFB) axotomizes and/or deafferents phenotypically identified neuronal populations important in the function of the basal ganglia. Semiquantitative in situ hybridization and immunohistochemical analysis demonstrated that the products of the immediateearly gene $c$-fos were induced postaxotomy in the noradrenergic neurons of the locus ceruleus (LC), but not in the dopaminergic neurons of the substantia nigra pars compacta (SNc). Analysis of the levels of mRNA, protein, and activity for tyrosine hydroxylase demonstrated that the LC neurons survive the injury while the SNc neurons degenerate. After MFB transection, Fos protein also was induced in the corpus striatum within $1 \mathrm{hr}$, first in large, putatively cholinergic neuronal populations followed at $3 \mathrm{hr}$ by the small, putatively GABAergic neurons. The substantia nigra pars reticulata and the subthalamic nucleus neuronal populations, deafferented by the MFB transection, also exhibited Fos induction beginning at $3 \mathrm{hr}$. The data suggest that expression of Fos in a neuronal population is correlative with respect to cell survival following either axotomy or deafferentation. Whether Fos induction following injury is either a necessary mechanism of cell survival or merely a marker of increased neuronal activity requires further investigation.
\end{abstract}

[Key words: tyrosine hydroxylase, $c$-fos, in situ hybridization, immunocytochemistry, degeneration, neuronal injury]

The biochemical cascade associated with axotomy induced neuronal degeneration and regeneration in central catecholamine systems was first described almost 20 years ago (Reis and Ross, 1973; Ross et al., 1975; Reis et al., 1978). In those experiments electrolytic lesions of the median forebrain bundle (MFB) at the level of the posterolateral hypothalamus simultaneously axo-

\footnotetext{
Received Sept. 9, 1992; revised Feb. 16, 1993; accepted Feb. 22, 1993.

We acknowledge the expert technical assistance of Ms. Kimberly Morel and Mr. Charles Carver. In addition we thank Dr. Bruce Volpe for providing assistance on the quantitation of histological material. This work was supported by NIH Grant MH44043 and a Parkinson's Foundation Grant.

Correspondence should be addressed to Tong H. Joh, Ph.D., Cornell University Medical College at the W. M. Burke Medical Research Institute, 785 Mamaroneck Avenue, White Plains, NY 10605.

Copyright $(C) 1993$ Society for Neuroscience $0270-6474 / 93 / 133472-13 \$ 05.00 / 0$
}

tomized both the dopaminergic neurons in the substantia nigra pars compacta ( $\mathrm{SNc}$ ) and the noradrenergic neurons in the locus ceruleus (LC). Axotomy of the LC neurons produced a characteristic triphasic response in the activity of tyrosine hydroxylase (TH), which consisted of an increase in enzyme activity to $150 \%$ of control over the first $2 \mathrm{~d}$, and then a reduction to $60 \%$ of control during the second week, and finally a return to near control activity levels by the fourth week (Reis and Ross, 1973; Ross et al., 1975). Quantitative morphometry and immunotitration studies demonstrated that these changes in activity were not the consequence of cell death in the LC but resulted from changes in the amounts of enzyme protein and not activation or deactivation of existing enzyme molecules (Reis et al., 1973; Ross et al., 1975).

In contrast, the axotomized dopaminergic neuronal population in the SNc underwent an entirely different biochemical response to injury. Electrolytic lesion of the MFB resulted in an increase in TH activity in the SNc to $175 \%$ of control levels by $24 \mathrm{hr}$ followed by a gradual but permanent reduction to $40 \%$ of control by 2 weeks. These changes in TH activity resulted from alterations in the amounts of TH protein (Reis et al., 1978). The cellular and molecular mechanisms underlying the differential response to axotomy in these two catecholaminergic neuronal populations have yet to be elucidated. Recently, the early alterations ( $<1$ week) in TH immunoreactivity and mRNA in the $\mathrm{SNC}$ and $\mathrm{LC}$ were analyzed following microknife transection of the MFB (Weiser et al., 1993). Within $24 \mathrm{hr}$ TH immunoreactivity increased in both the axotomized $\mathrm{SNc}$ and $\mathrm{LC}$. However, semiquantitative in situ hybridization revealed a postaxotomy TH mRNA increase in the LC, but not in the SNc, suggesting that, in the $\mathrm{LC}$, at least a portion of the increase in TH immunoreactivity and enzyme activity was a consequence of new protein synthesis and not lesion-induced protein pile-up as previously hypothesized. Notably, the increase in TH mRNA levels in the LC was preceded by an increase in the levels of expression of the c-fos gene products (Weiser et al., 1993). The delayed molecular events, especially as related to neuronal survival in these and other neuronal populations in the basal ganglia circuitry, have not been elucidated using this type of acute lesion.

Lesions of the SNc have often been utilized as a model of Parkinson's disease (PD) (Bernheimer et al., 1973). Many experimental paradigms have studied the effects of relatively slow and long-term dopamine depletion since the large reduction in the number of dopaminergic projection neurons in the $\mathrm{SNC}$ and the subsequent depletion of dopamine in the corpus striatum (CS) in PD also is a slow process. A number of these studies have employed the dopamine neuron specific neurotoxin 
6-hydroxydopamine (6-OHDA). However, the relatively protracted degenerative response following 6-OHDA may hinder observation of early or transient molecular events that may trigger a neurons response to injury. Furthermore, compensatory responses following administration of 6-OHDA that occur in both the SNc neurons and in the nigrostriatal circuitry may also impede analysis during this prolonged process (Zigmond et al., 1990). For example, both GABAergic (Ribak et al., 1979; Mugnaini and Oertel, 1985; Kubota et al., 1987a) and cholinergic neurons (Kubota et al., 1987b) in the CS, which receive input from dopaminergic SNc neurons, exhibit biochemical alterations after 6-OHDA administration (Vincent et al., 1978; Herman et al., 1988; Jackson et al., 1988; Segovia et al., 1990, 1991). A microknife transection of the MFB, similar to the electrolytic lesions previously employed (Reis and Ross, 1973) and which instantly damages the axons of the dopaminergic projection neurons, can be utilized to detect either immediate or transient cellular events that occur in response to axotomy. Lesions of this type also may facilitate observation of immediate or transient events occurring in response to dopamine depletion in the deafferented neurons of the CS.

Recent evidence has suggested that immediate-early genes, such as c-fos, may play important roles in the development of the long-term dopamine-related deficits in the CS (Robertson et al., 1991). Immediate-early genes are believed to bridge the gap between extraccllular stimulus/response cascades to longerterm changes in gene function (Morgan and Curran, 1989; Doucet et al., 1990). Fos has been shown to act as one part of a DNA complex along with another immediate-early gene, c-jun, in order to regulate the synthesis of many genes (Morgan and Curran, 1989). Fos/Jun complexes may influence both neurotransmitter synthesis and function via the presence of an AP-1 site on a particular target gene (Franza et al., 1988; GizangGinsberg and Ziff, 1990; Sheng and Greenberg, 1990). Experimentally, it has been demonstrated that c-fos expression is induced following stress (Ceccatelli et al., 1989) and kindling (Dragonow and Robertson, 1987b), by depolarization subsequent to application of neurotransmitters (Greenberg et al., 1985), membrane depolarization with potassium (Bartel et al., 1989), induction of seizures by drugs or electrical stimulation (Dragonow and Robertson, 1987a; Morgan et al., 1987), peripheral sensory stimulation (Hunt et al., 1987; Jones and Evinger, 1991), and the administration of growth factors (Greenberg et al., 1985). These experiments suggested that c-fos expression is correlated with increased neuronal activity following depolarization. If increased neuronal activity is a concomitant of cell survival, we hypothesize that expression of Fos (a potential marker of neuronal activity) upon axotomy or deafferentation might allow us to predict the eventual fate of a neuron.

The comparison between the early gene response of neurons directly and indirectly injured by axotomy and deafferentation has not been examined. Unilateral transection of the MFB axotomizes dopaminergic neurons in the $\mathrm{SNc}$, noradrenergic neurons in the LC, striatonigral GABAergic neurons in the $\mathrm{CS}$, and GABAergic neurons in the globus pallidus (GP). In addition, it deafferents striatopallidal GABAergic neurons in the CS, cholinergic neurons in the $C S$, glutamatergic neurons in the subthalamic nucleus (STN), and GABAergic neurons in the substantia nigra pars reticulata ( $\mathrm{SNr}$ ). In order to examine the longer-term consequences of axotomy and deafferentation, these studies focused on the genomic response of neurons to transection of the MFB.

\section{Materials and Methods}

Lesions. Male Sprague-Dawley rats (Charles River Laboratories, Kingston, $\mathrm{NY})(n=3 /$ time point), approximately $250 \mathrm{gm}$ body weight, were anesthetized with an intraperitoneal injection $(40 \mathrm{mg} / \mathrm{kg})$ of sodium pentobarbital (Nembutal, Butler Co., Columbus, $\mathrm{OH}$ ). Animals were placed in a stereotaxic apparatus and a unilateral transection was made of the MFB (-3.0 AP, +0.6 LAT, $-8.8 \mathrm{DV})$ using a Kopf wire knife. The animals were allowed to recover from the anesthesia and were killed at various time points from $1 \mathrm{hr}$ to 6 weeks posttransection.

Immunohistochemistry. Animals were deeply anesthetized with sodium pentobarbital $(120 \mathrm{mg} / \mathrm{kg})$ and perfused transcardially with saline containing $0.5 \%$ sodium nitrate and $10 \mathrm{U} / \mathrm{ml}$ heparin sulfate followed by cold $4 \%$ formaldehyde generated from paraformaldehyde in $0.1 \mathrm{M}$ sodium phosphate buffer, $\mathrm{pH}$ 7.2. The brains were postfixed in the same fixative for $1 \mathrm{hr}$ and embedded in $30 \%$ sucrose overnight. Free-floating sections $(40 \mu \mathrm{m})$, obtained on a freezing microtome, were washed for $30 \mathrm{~min}$ in $0.1 \mathrm{M}$ sodium phosphate-buffered saline (PBS) and preincubated with $1 \%$ bovine serum albumin (BSA) and $0.2 \%$ Triton X-100 in $0.1 \mathrm{M}$ PBS. Sections were washed in PBS containing $0.5 \% \mathrm{BSA}$ and incubated overnight with TH or Fos antisera (Fos and related antigens) (1:25,000 for TH and 1:3000 for Fos; Cambridge Research). Sections were washed in PBS-BSA and incubated for $1 \mathrm{hr}$ with biotinylated antirabbit IgG $(\mathrm{TH})$ or anti-sheep IgG (Fos) (Vector Laboratories, Burlingame, CA). The tissue was washed and incubated for $1 \mathrm{hr}$ with the avidin-biotin horseradish peroxidase complex according to Vector Elite kit instructions (Vector Laboratories, Burlingame, CA). The antigens were visualized by reaction with 3,3-diaminobenzidine tetrahydrochloride as a chromogen and $0.003 \%$ hydrogen peroxide for $5 \mathrm{~min}$. Sections were mounted on gelatin-coated slides, dehydrated through graded ethanols, and coverslipped with Permount.

In situ hybridization. Animals were perfused and brain sections obtained as above. Sections were placed in vials containing $2 \times$ sodium chloride-sodium citrate (SSC) ( $1 \times \mathrm{SSC}$ is $0.15 \mathrm{M}$ sodium chloride and $0.015 \mathrm{M}$ sodium citrate) and $50 \mathrm{~mm}$ dithiothreitol (DTT). Tissues were prehybridized in 50\% formamide, $10 \%$ dextran, $2 \times \mathrm{SSC}, 1 \times$ Denhardt's solution, $10 \mathrm{mM}$ DTT, and $0.5 \mathrm{mg} / \mathrm{ml}$ sonicated and denatured salmon sperm DNA. Denatured ${ }^{35} \mathrm{~S}$-dCTP-labeled cDNA probe (TH, 400 base pairs; c-fos, 1.1 kilobases obtained from American Type Culture Collection) was added to the vial $\left(10 \times 10^{6} \mathrm{cpm}\right.$ per vial) and hybridization was carried out overnight at $48^{\circ} \mathrm{C}$. The sections were washed in serial dilutions of SSC at $48^{\circ} \mathrm{C}$, starting with $2 \times$ SSC and ending with $0.1 \times$ SSC. After a $15 \mathrm{~min}$ wash in $0.05 \mathrm{~m}$ phosphate buffer, sections were mounted and dehydrated. For determination of optimum development time, slides were apposed to Kodak XAR-5 film for 48-72 hr at room temperature. Slides were subsequently dipped in Kodak NTB-2 emulsion and exposed at $4^{\circ} \mathrm{C}$ for 5-14 d. After developing in Kodak D-19 developer at $16^{\circ} \mathrm{C}$, sections were fixed in Kodak Fixer, counterstained with cresyl violet, dehydrated, and coverslipped.

TH enzyme assay. Animals were killed by decapitation, and the brains were quickly removed and dissected on ice. Tissue of interest was immediately frozen in liquid nitrogen and stored at $-80^{\circ} \mathrm{C}$ until enzyme assays were performed. For TH biochemical analysis, the tissue was homogenized in 10-20 vol of ice-cold $5 \mathrm{~mm}$ potassium phosphate buffer, pH 7.0 , containing $0.2 \%$ Triton $\mathrm{X}-100$ and clarified by centrifugation for $15 \mathrm{~min}$ at $10,000 \times g$. The supernatant was assayed by a modification (Baker, 1990) of the method of Coyle (1972). Activity was expressed as nanomoles of dopamine formed per $15 \mathrm{~min}$ per milligram of protein. Protein concentrations were determined for each tissue by the Lowry method (Lowry et al., 1951).

Lesion verification. In order to verify the site of the microknife transection, alternate tissue sections were collected through the lesion site and processed for either TH immunocytochemistry or Nissl staining. For time points longer than $2 \mathrm{~d}$ tissue sections from the corpus striatum were also processed for TH immunocytochemistry to demonstrate loss of nigrostriatal input.

Quantitative analysis. The relative amounts of TH mRNA and protein in the neuronal populations of interest were measured on slides using a Zeiss IBAS 20 image analysis system. This system allows for the measurement of regional optical densities and silver grain counting (see Weiser et al., 1993, for details). In order to account for changes in either brain region or neuronal size, area was also measured. The absolute quantities of mRNA or protein present using in situ hybridization or immunohistochemistry cannot be determined with confidence. Therefore, the results are expressed as the percentage of contralateral control \pm the standard error of the mean. In preliminary studies, it was deter- 

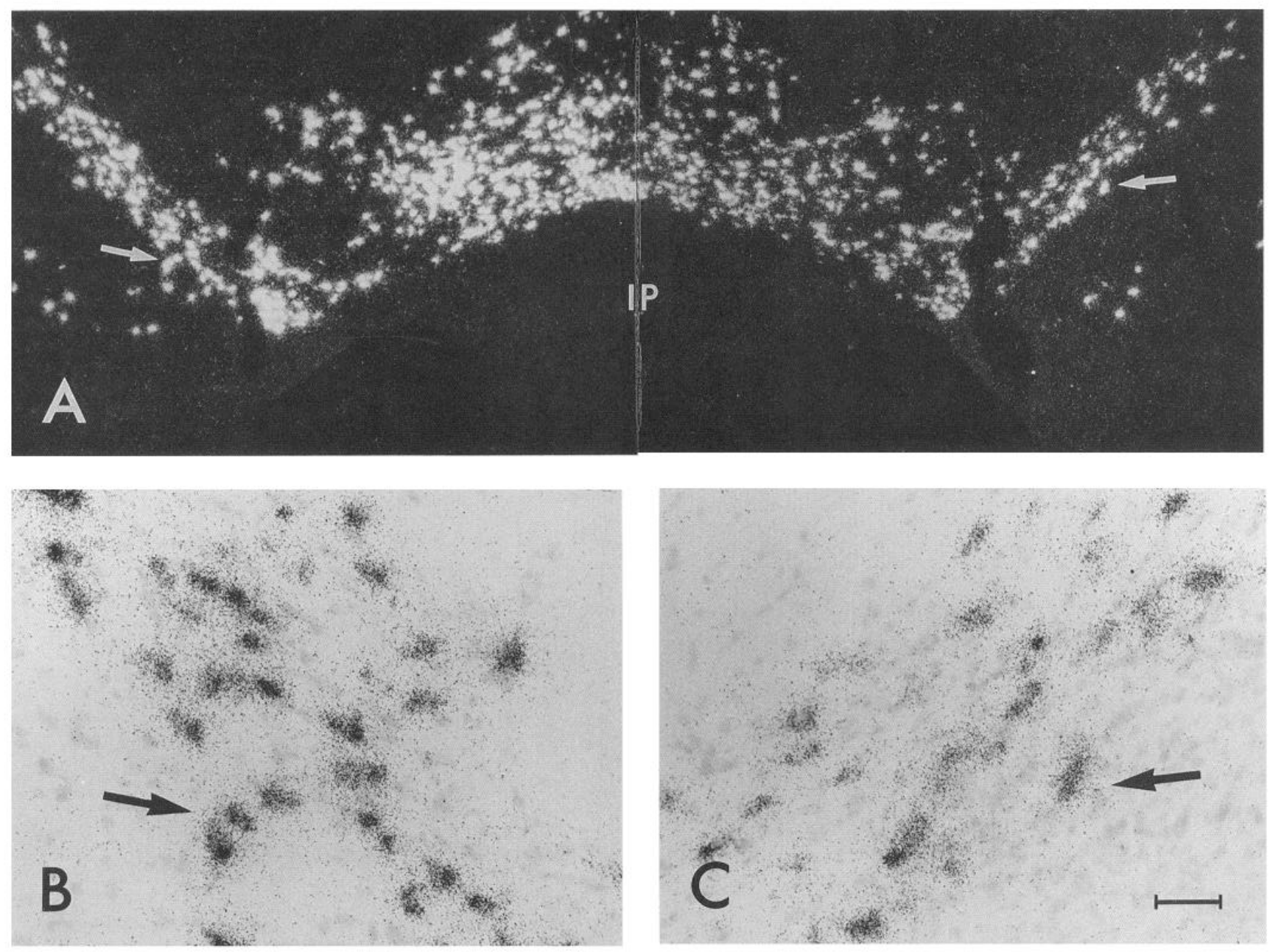

Figure 1. TH mRNA as visualized by in situ hybridization in the SNc $7 \mathrm{~d}$ after unilateral transection of the MFB. $A$, Low-power dark-field photomicrograph of the SNc demonstrating the reduction in TH mRNA (fewer silver grains) on the lesioned side (right). $B$ and $C$, High-power bright-field photomicrographs of $A$ clearly demonstrating that the reduction in TH mRNA in the SNc is most likely the consequence of a reduction in the number of grains per cell. Note that a few neurons on the side ipsilateral to the lesion, for example, arrow in $C$, possess near control levels of TH mRNA. Cells indicated by small arrows in $A$ are seen at higher magnification in $B$ and $C$. $I P$, interpeduncular nucleus. Scale bar: $225 \mu$ m for $A, 45 \mu \mathrm{m}$ for $B$ and $C$.

mined that the contralateral side is a consistent representation of both normal and sham-lesioned control animals.

Statistical analysis. Statistical significance between the control and lesioned sides was determined by an analysis of variance (ANOVA) and post hoc least significant differences using the STATVIEW statistical analysis program on an Apple Macintosh computer.

\section{Results}

TH enzyme activity

The effect of axotomy on the TH activity in the CS, SNc, and LC was determined at $7,10,14,28$, and $58 \mathrm{~d}$ posttransection of the MFB. Values for the ipsilateral lesioned side are calculated as a percentage of the side contralateral to the transection, which is set at $100 \%$. The values at time zero (in $\mathrm{nmol} / 15 \mathrm{~min} / \mathrm{mg}$ tissue \pm SEM; CS, $5.94 \pm 0.46 ;$ SNc, $1.94 \pm 0.16 ; \mathrm{LC}, 1.97 \pm$ 0.09 ) represent control animals where there was no left-right difference. $\mathrm{TH}$ activity in the CS was significantly and permanently reduced to $14 \%$ of control by $7 \mathrm{~d}(\mathrm{CS}, 0.83 \pm 0.09)$. In comparison, the decline in $\mathrm{TH}$ activity in the $\mathrm{SNc}$ was more protracted, reaching only $82 \%$ of control at $7 \mathrm{~d}$ (SNc, $1.6 \pm$ 0.07 ) and decreasing to its nadir, $32 \%$, at $58 \mathrm{~d}$ (SNc, $0.62 \pm$
0.05 ). In contrast, the decline in $\mathrm{TH}$ activity in the LC was not permanent. TH activity in the LC was reduced to $51 \%$ of control by $14 \mathrm{~d}(\mathrm{LC}, 1.00 \pm 0.08)$ but returned to control levels by 28 d $($ LC, $1.99 \pm 0.10)$.

\section{$T H$ in situ hybridization}

The effect of axotomy on TH mRNA, as revealed by in situ hybridization in the SNc is illustrated in Figure $1 A-C$. TH mRNA in the SNc ipsilateral to the lesion was reduced to $62 \%$ after 7 $\mathrm{d}$ as compared to the contralateral unlesioned side (Fig. 2A). Although the levels of TH mRNA in most SNc neurons appear decreased, there remained a few neurons with normal levels of expression. In contrast, a transient increase in TH mRNA expression was observed in the LC at $72 \mathrm{hr}$. The complete analysis of these early events was examined previously (Weiser et al., 1993). At both 7 and 14 d, the level of TH mRNA in the neurons of the LC (Fig. $3 B-D$ ) was reduced below control levels when quantitated by regional optical density ( $31 \%$ of control; Fig. $2 A)$ or silver grain counting ( $30 \%$ of control; Fig. $2 A$, inset). Previous studies demonstrated that the loss of $\mathrm{TH}$ activity and immu- 

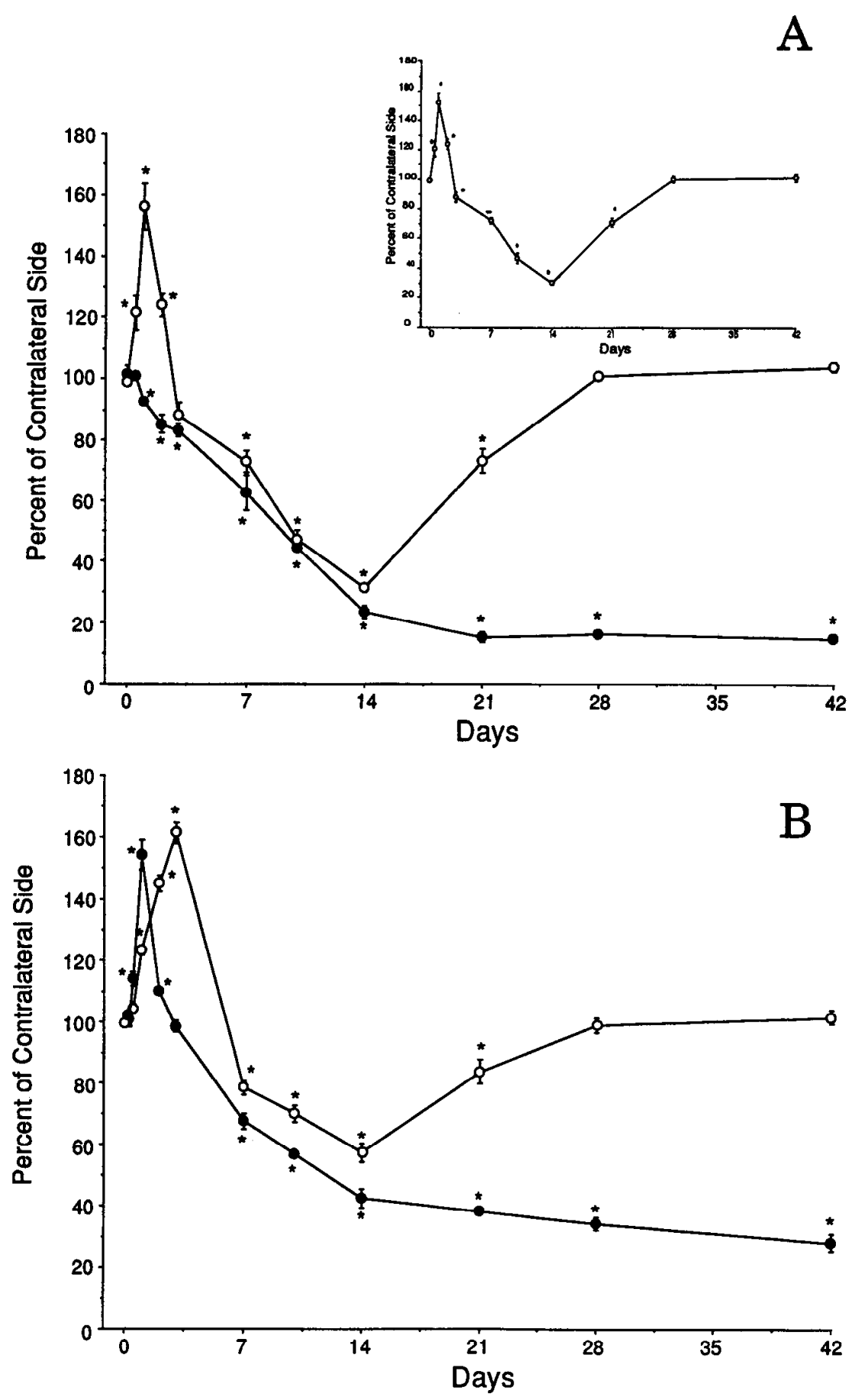

Figure 2. A, Time course changes in regional optical density of silver grains produced by in situ hybridization for TII mRNA in the SNc (solid circles) and the LC (open circles) after unilateral transection of the MFB. Inset confirms that the quantitation of the in situ hybridization by regional optical density is a valid representation of the number of silver grains per neuron in the LC. $B$, Time course of the changes in density of TH immunoreactivity in the $\mathrm{SNc}$ (open circles) and the LC (solid circles) after unilateral transection of the MFB as indicated by regional optical density. In $A, B$, and inset, values for the ipsilateral lesioned side are calculated as a percentage of the side contralateral to the transection, which is set at $100 \%$. The values at time zero (mean OD \pm SEM: SNc mRNA, $0.45 \pm 0.07 ; \mathrm{LC}$ mRNA, $0.51 \pm 0.09$; mean number of grains per cell \pm SEM: LC mRNA, 33 \pm 1.9 ; mean OD \pm SEM: $\mathrm{SNc}$ protein, $0.20 \pm 0.02 ;$ LC protein, $0.35 \pm 0.05$ ) represent control animals where there was no left-right difference. Data were analyzed by ANOVA and post hoc least significant difference. ${ }^{*}$ indicates significant differences between control and experimental animals at $P<0.05$. noreactivity was not the result of a reduction in the number of LC neurons (Reis et al., 1978).

At 6 weeks postaxotomy, TH mRNA levels in the SNc had dcclincd to $15 \%$ of control values (Figs. $2 A, 4 A-C$ ). In contrast to the results for the $\mathrm{LC}$, this loss was most likely due to the reduction in the number of SNc neurons. As in the 1 week transection, a few remaining neurons still exhibited normal or high levels of TH mRNA.

\section{TH immunohistochemistry}

The effect of axotomy on TH immunoreactivity in the $\mathrm{SNc}$ is illustrated in Figure $6 A-C$. Following a transient increase (see
Weiser et al., 1993, for details), TH immunoreactivity in the $\mathrm{SNc}$ was reduced to $68 \%$ of control at $7 \mathrm{~d}$ postaxotomy (Fig. $2 B$ ). In addition, TH immunoreactivity also was reduced in the dendrites of the SNc neurons located in the SNr (Fig. $5 D, E$ ). This loss of TH immunoreactivity in the dendrites may account for a significant proportion of the decrease in $\mathrm{TH}$ activity observed at 1 week. In the LC, a transient increase in TH immunoreactivity occurred between 48 and $72 \mathrm{hr}$ (see Weiser et al., 1993, for details). In contrast to the $\mathrm{SNc}, \mathrm{TH}$ immunoreactivity in the LC is only very slightly reduced at 1 week (not shown) but approaches $57 \%$ of control, its nadir, by 2 weeks (Figs. $2 B, 3 A$ ). In comparison, TH immunoreactivity in the 

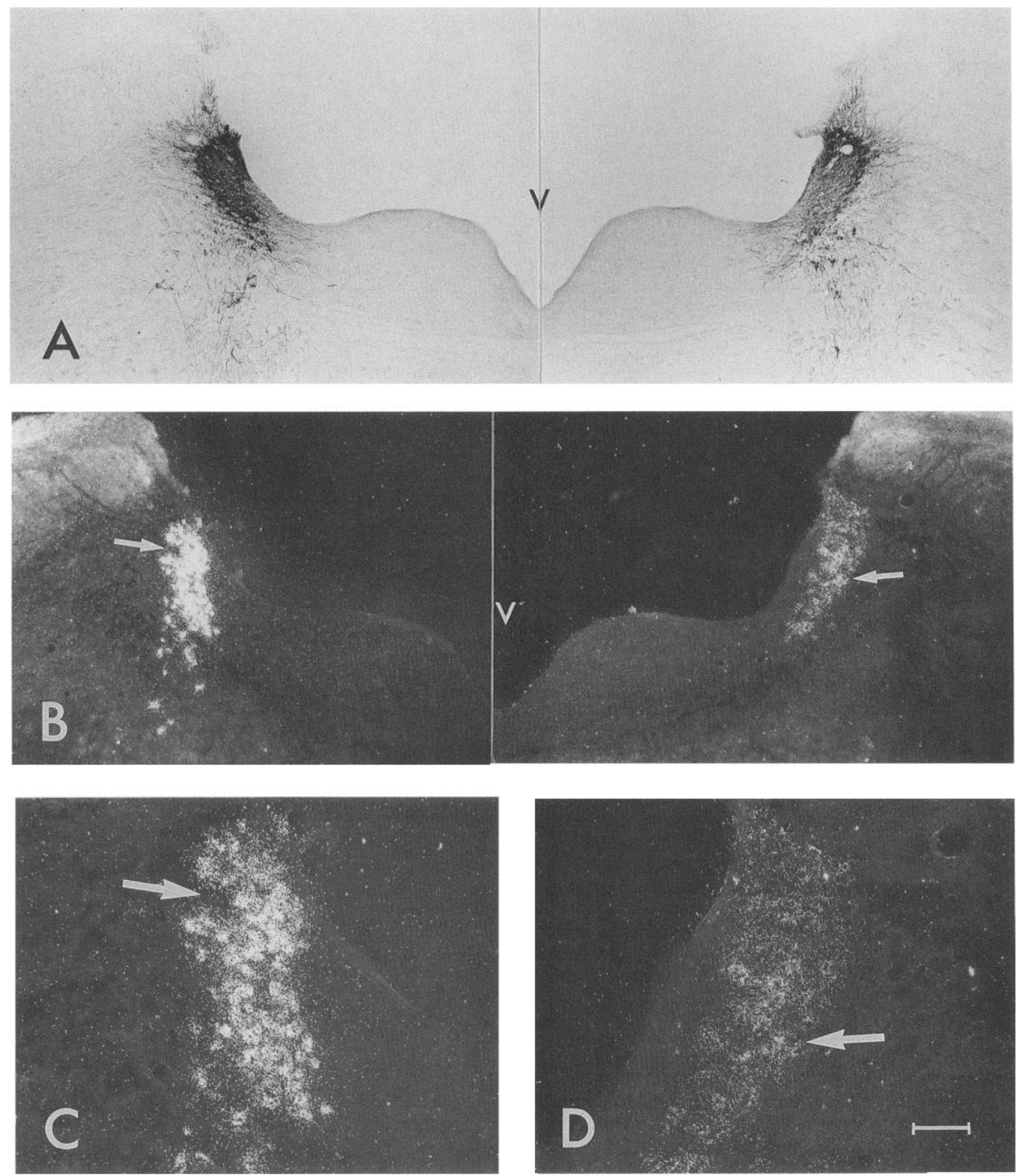

Figure 3. TH immunoreactivity and in situ hybridization in the LC $14 \mathrm{~d}$ after unilateral transection of the MFB. $A$, Low-power bright-field photomicrograph of TH immunoreactivity in the LC demonstrating reduced immunostaining (see Fig. 2 for quantitation) on the lesioned side (right). B, Low-power dark-field photomicrograph of TH mRNA in the LC demonstrating the decrease in the number of silver grains on the lesioned side (see Fig. $2 A$, inset, for quantitation). Arrows in $B$ indicate regions shown at higher magnification in $C$ and $D$. $V$, third ventricle. Scale bar: $225 \mu \mathrm{m}$ for $A$ and $B, 90 \mu \mathrm{m}$ for $C$ and $D$. 

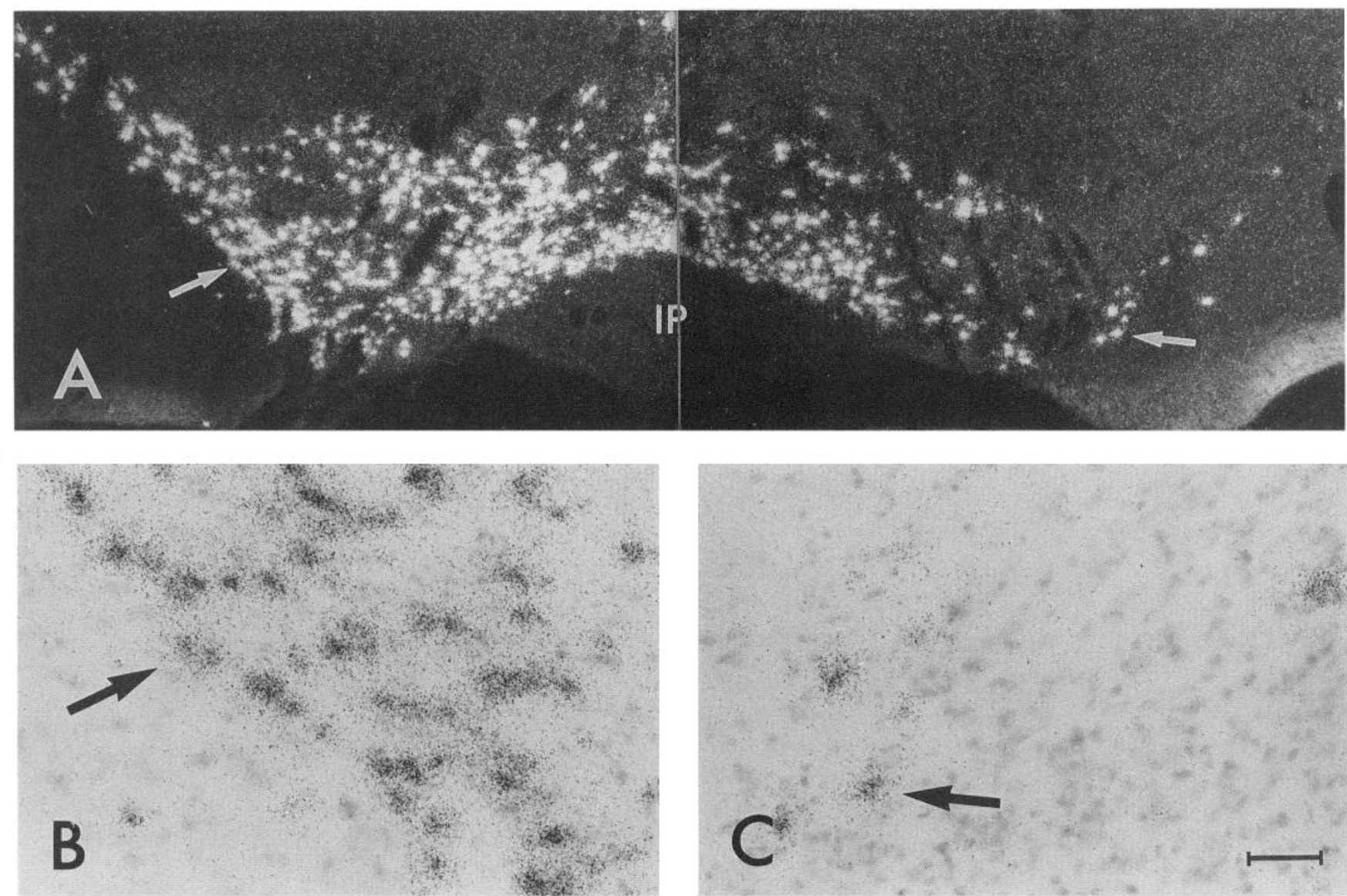

Figure 4. TH mRNA as visualized by in situ hybridization in the SNc 6 weeks after unilateral transection of the MFB. $A$, Low-power dark-field photomicrograph of the SNc demonstrating the large reduction in TH mRNA (silver grains) on the lesioned side (right). $B$ and $C$, High-power bright-field photomicrographs of $A$ clearly demonstrating the reduction in TH mRNA silver grains in the SNc is most likely the consequence of the loss of TH neurons. Note that a few neurons (e.g., $C$, arrow) of the lesioned side $(C)$ possess near control levels of TH mRNA. Cells indicated by small arrows in $A$ are seen at higher magnification in $B$ and $C$. $I P$, interpeduncular nucleus. Scale bar: $225 \mu \mathrm{m}$ for $A, 45 \mu \mathrm{m}$ for $B$ and $C$.

terminal field in the CS is reduced permanently to below $20 \%$ of control values by $48 \mathrm{hr}$ (Fig. $7 \mathrm{~A}$ ).

The effects on $\mathrm{TH}$ immunoreactivity in the SNc 6 weeks postaxotomy are illustrated in Figure $6 A-C$. TH immunoreactivity is significantly reduced to $28 \%$ on the lesion side with very few TH-positive neurons remaining (Fig. $2 B$ ). In comparison to $7 \mathrm{~d}$ postaxotomy, there appear to be very few remaining $\mathrm{TH}$-positive dendrites in the $\mathrm{SNr}$ (Fig. $6 D, E$ ).

In addition to the intensity of TH staining, the immunoreactive areas of the CS, SNc, and LC were measured and are illustrated in Figure 7, $A$ and $B$. The area of the TH immunoreactivity in the CS decreased moderately but permanently to $83 \%$ of the contralateral side by $21 \mathrm{~d}$ (Fig. $7 A$ ). In contrast, the SNc immunoreactive area was decreased to $40 \%$ of the contralateral side by this same time point (Fig. $7 B$ ). On the other hand, in the LC, the TH immunoreactive area increased to $112 \%$ by $72 \mathrm{hr}$ and returned to control levels by $7 \mathrm{~d}$ (Fig. $7 \mathrm{~B}$ ). This small increase in area may be a reflection of an increase in $\mathrm{TH}$ immunoreactivity within LC fibers.

\section{Fos immunohistochemistry and in situ hybridization}

The early effects following axotomy of the MFB on Fos immunoreactivity in the CS are illustrated in Figure $9 A-D$ and Table 1 . Beginning at $1 \mathrm{hr}$, reaching a maximal expression at
$90 \mathrm{~min}$ and returning to baseline by $3 \mathrm{hr}$, large cells, putatively cholinergic interneurons in the CS, exhibited a large induction of their nuclear expression of Fos immunoreactivity. This robust induction was most pronounced in the ventrolateral striatum.

Small, putatively GABAergic, neurons in the CS increased their expression of Fos immunoreactivity beginning at $3 \mathrm{hr}$ and returning to control levels by $12 \mathrm{hr}$ (Fig. $8 E-G$, Table 1 ). The Fos response was most pronounced in the lateral striatum.

Table 1. Summary of time-dependent Fos expression in the CS and substantia nigra after transection of the MFB

\begin{tabular}{llllllll} 
Region & Control & $1 \mathrm{hr}$ & $1.5 \mathrm{hr}$ & $3 \mathrm{hr}$ & $6 \mathrm{hr}$ & $12 \mathrm{hr}$ & $24 \mathrm{hr}$ \\
\hline CS (p) lg & 0 & 2 & 3 & 0 & 0 & 0 & 0 \\
CS (p) s & 0 & 0 & 0 & 3 & 1 & 0 & 0 \\
SNr (m) & 0 & 0 & 2 & 3 & 1 & 0 & 0 \\
SNr (p) & 0 & 0 & 0 & 2 & 3 & 1 & 0 \\
STN (p) & 0 & 0 & 0 & 2 & 3 & 0 & 0 \\
SNc (p) & 0 & 0 & 0 & 0 & 0 & 0 & 0
\end{tabular}

The values indicate the relative number of cells containing nuclear Fos labeling in each neuronal population: 0 , no Fos immunoreactive labeling; 1 , sparse labeling 2 , moderate labeling; 3 , extensive labeling. $\mathrm{lg}$, large neurons, $\mathrm{s}$, small neurons; $\mathrm{m}$, mRNA; p, protein. 

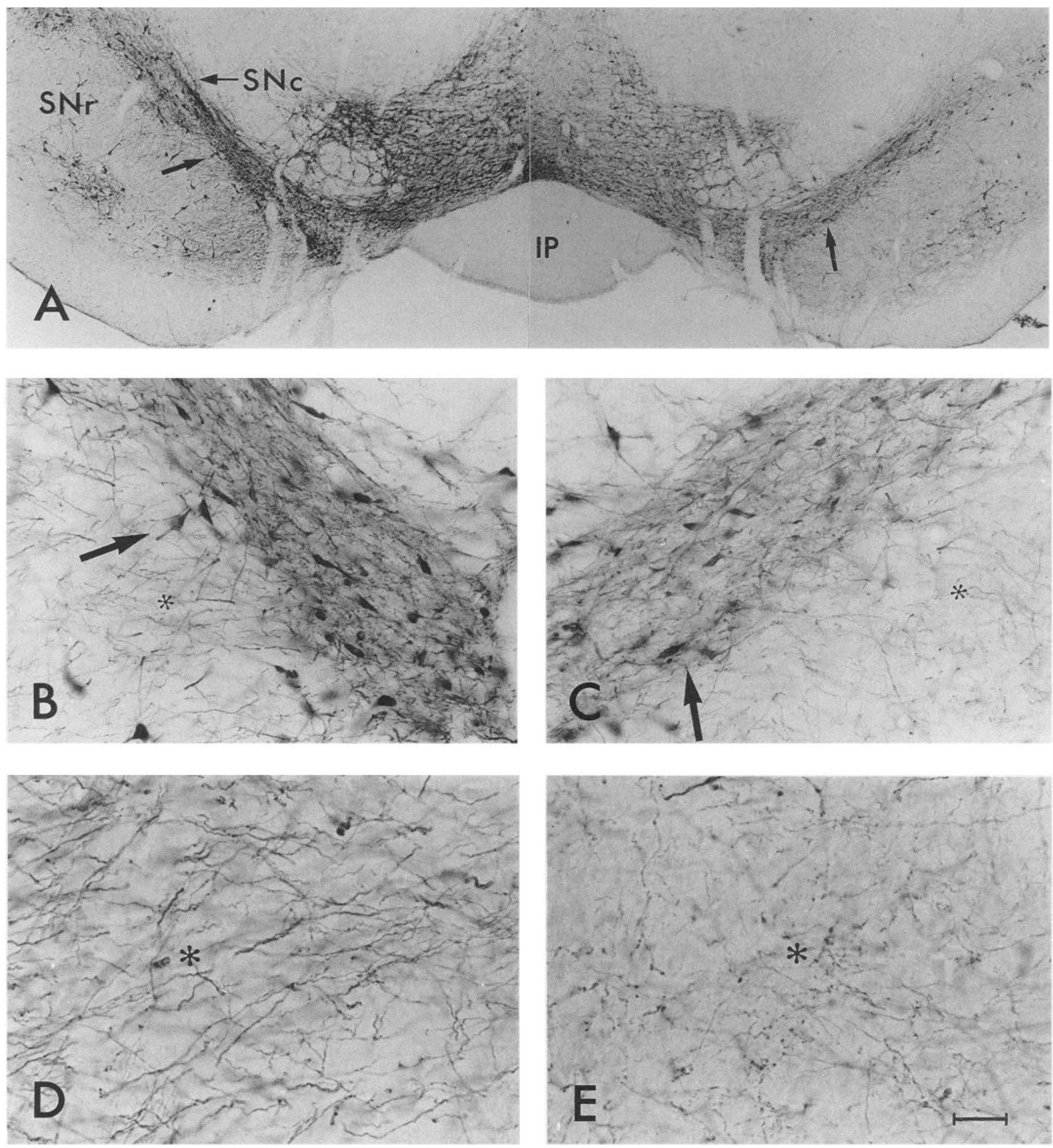

Figure 5. TH immunoreactivity in the SNc $7 \mathrm{~d}$ after unilateral transection of the MFB. A, Low-power bright-field photomicrograph demonstrating the slight decrease in the intensity of TH staining in the lesioned side (right). $B$ and $C$, High-power bright-field photomicrographs of the area near arrows in $A . D$ and $E$, High-power bright-field photomicrographs of the dendrites of the SNc located in the SNr. Note the patchy staining within the individual dendrites in $E$. Asterisks in $B$ and $C$ demarcate area seen at higher power in $D$ and $E$. $I P$,interpeduncular nucleus. Scale bar: 225 $\mu \mathrm{m}$ for $A, 45 \mu \mathrm{m}$ for $B$ and $C$, and $22 \mu \mathrm{m}$ for $D$ and $E$.

Small neurons of the $\mathrm{SNr}$ exhibited a robust c-fos mRNA expression beginning at $90 \mathrm{~min}$ and reaching maximal expression at $6 \mathrm{hr}$ (Fig. 9A, Table 1). On the other hand, Fos protein expression began at $3 \mathrm{hr}$ and continued for up to $12 \mathrm{hr}$ (Fig. $9 B$,
Table 1). Neurons in the STN also increased their Fos immunoreactivity, but their expression did not occur until 3-6 hr postaxotomy and continued up to $12 \mathrm{hr}$ (Fig. 9C, Table 1). Surprisingly, axotomized neurons of the SNc did not at any time 

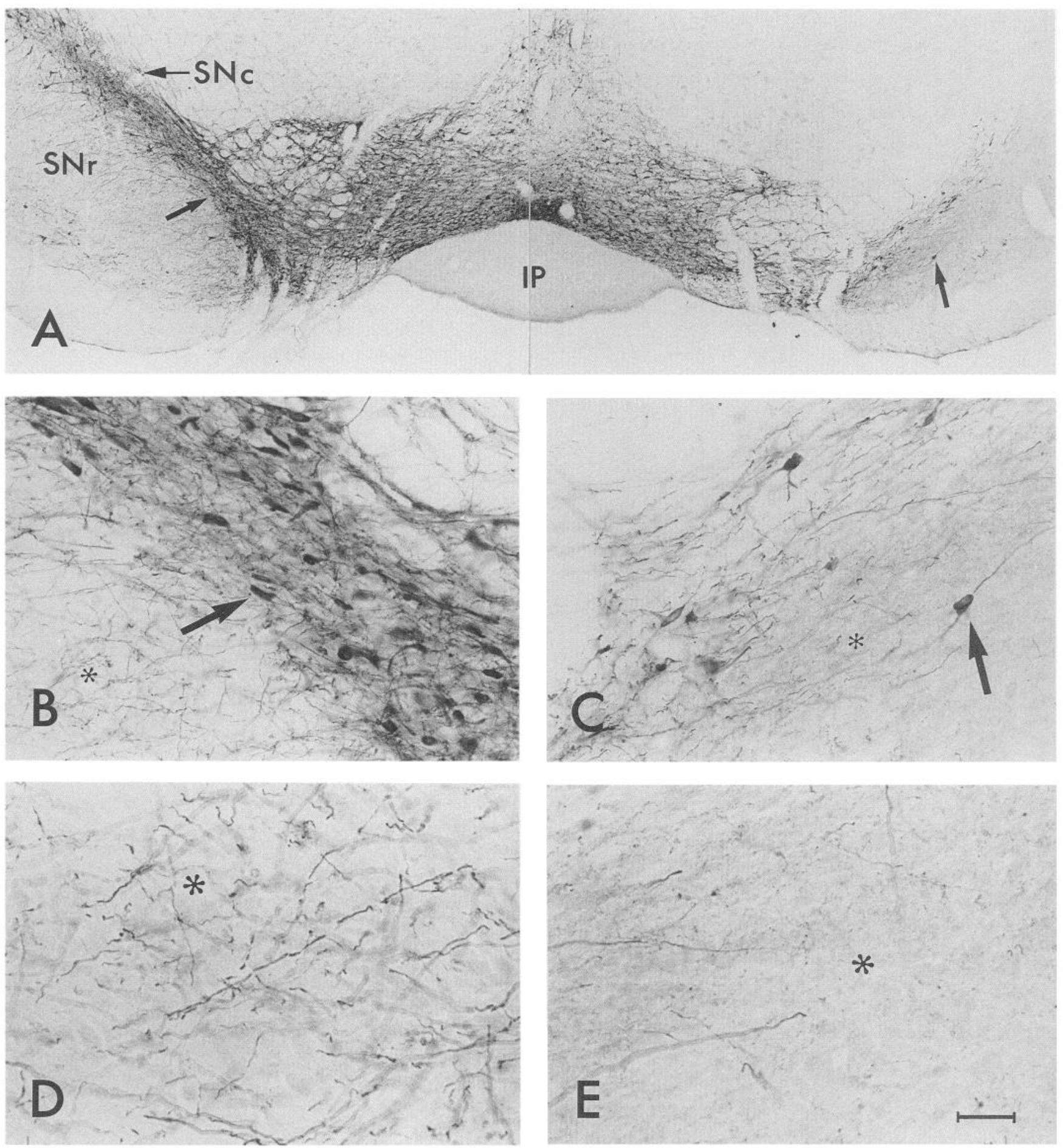

Figure 6. TH immunoreactivity in the SNc 6 weeks after unilateral transection of the MFB. $A$, Low-power bright-field photomicrograph demonstrating the large decrease in the intensity of TH staining on the lesioned SNc (right). $B$ and $C$, High-power bright-field photomicrographs of the area near arrows in $A . D$ and $E$, High-power bright-field photomicrographs of the dendrites of the SNc located in the SNr. Note the loss of TH staining in the dendrites in $E$. Asterisks in $B$ and $C$ demarcate area seen at higher power in $D$ and $E$. $I P$, interpeduncular nucleus. Scale bar: 225 $\mu \mathrm{m}$ for $A, 45 \mu \mathrm{m}$ for $B$ and $C, 22 \mu \mathrm{m}$ for $D$ and $E$.

point examined demonstrate any Fos immunoreactivity or mRNA. In contrast, recent experiments have demonstrated that axotomized neurons of the LC show a large and sustained increase in Fos immunoreactivity beginning at $3 \mathrm{hr}$ and remaining elevated for up to $24 \mathrm{hr}$ (Weiser et al., 1993).

\section{Discussion}

Recent reports indicate that the levels of neurotransmitter biosynthetic enzyme mRNA and protein may not be correlated following neuronal injury (Nowak et al., 1990; Weiser et al., 

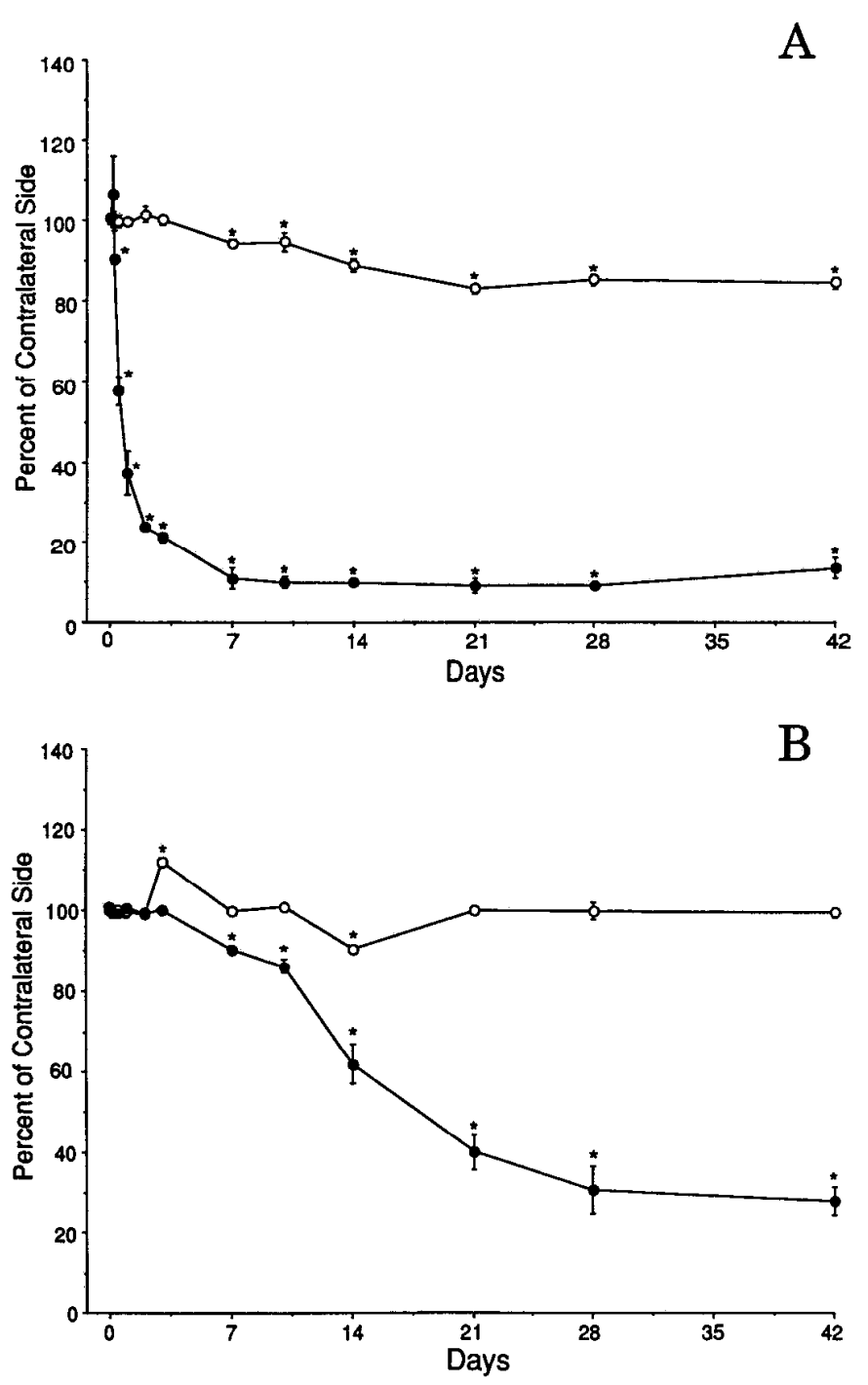

Figure 7. A, Time course for the changes in optical density (solid circles) and area (open circles) of TH immunoreactivity in the CS after unilateral transection of the MFB. $B$, Time course for the changes in area of TH immunoreactivity in the SNc (solid circles) and the LC (open circles) after unilateral transection of the MFB. In both $A$ and $B$, values for the ipsilateral lesioned side are calculated as a percentage of the side contralateral to the transection, which is set at $100 \%$. The values at time zero (mean CS area, $\mathrm{mm}^{2} \pm$ SEM, $7.87 \pm 0.06$; mean CS OD, $0.11 \pm$ 0.01 ; mean SNc area, $\mathrm{mm}^{2} \pm \mathrm{SEM}, 0.292 \pm 0.02$; mean LC area, $\mathrm{mm}^{2}$ \pm SEM, $0.114 \pm 0.012$ ) represent control animals where there was no left-right difference. Data were analyzed by ANOVA and post hoc least significant difference. ${ }^{*}$ indicates significant differences between control and experimental animals at $P<0.05$.

1991, 1993). However, the present studies have demonstrated that the long-term postaxotomy alterations in TH mRNA and protein in catecholamine neurons are positively correlated. As expected, the changes in mRNA preceded and exceeded the changes in enzyme protein and, presumably, activity. In addition, the nadir in TH mRNA levels in the axotomized SNc and $\mathrm{LC}$ is lower than that for TH activity and protein.

Although for the most part TH mRNA and protein expression in the SNc and LC correlated with the changes in TH activity, a higher-resolution examination revealed that a few neurons in the SNc express near normal levels of TH mRNA as long as 6 weeks postaxotomy. It has been suggested that the delayed man- ifestation of clinical symptoms in PD may be due to the unique ability of the surviving SNc dopaminergic neurons to upregulate their synthesis and release of dopamine (Pasinetti et al., 1989; Zigmond et al., 1990). Dopaminergic neurons, spared after injection of the slowly acting dopamine neurotoxin 6-OHDA, increased both their synthesis of and the quantity of dopamine released in the CS (Zigmond et al., 1990; Calne and Zigmond, 1991). In contrast to the effects of 6-OHDA administration (Pasinetti et al., 1992), normal TH mRNA levels are observed in those neurons that appear to survive the axotomy. The difference between the model systems could be attributed to the fact that the application of intranigral 6-OHDA would not damage the GABAergic striatonigral input and thus regulation through this pathway would not be influenced. In the axotomy model, the complete transection of the MFB should prevent any terminal field regulation of compensatory responses. One also may hypothesize that the neurons remaining following MFB transection either project to or receive compensatory influences from other sites. For example, it is known that a small population of nigral neurons (5-10\%) innervate the contralateral striatum (Fass and Butcher, 1981; Laughlin and Fallon, 1982).

The present experiments also demonstrated that transection of the MFB produced a differential induction of the immediateearly gene $c-f o s$ in the striatum. The large, putatively cholinergic, interneurons, thought to direct translation of nigrostriatal dopaminergic transmission to motor patterns (Lloyd, 1978), respond most rapidly. These large $\mathrm{D}_{2}$-containing cholinergic interneurons receive direct synaptic input from dopaminergic $\mathrm{SNc}$ axons (Scatton et al., 1982; Kubota et al., 1987b). The induction of Fos in these large cells was most pronounced in the ventrolateral portion of the striatum. A similar gradient was seen both in the high-affinity dopamine uptake system demonstrated in the normal non-dopamine-depleted animal (Marshall et al., 1990) and in the levels of expression of $\mathrm{D}_{2}$ receptors following 6-OHDA (Joyce, 1991). Interestingly, Graybiel and coworkers conclude from double labeling experiments that direct or indirect dopamine agonists do not induce c-fos-like proteins in the cholinergic interneurons of the striatum (Graybiel, 1991; Berretta et al., 1992). The expression of c-fos in the CS cholinergic neurons following MFB transection may be related more to the consequences of the transection on the levels of CS dopamine than to the ability to activate specific dopamine receptor subtypes pharmacologically (see below).

The appearance of Fos in the large neurons of the CS at $1 \mathrm{hr}$ was followed at $3 \mathrm{hr}$ by expression in the small, putatively GABAergic, neurons. Dopaminergic axons originating in the SNc also make direct synaptic connections with the mediumsized $D_{1}$ - and $D_{2}$-containing GABAergic neurons in the striatum (Kubota et al., 1987a). Directly acting $D_{1}$ but not $D_{2}$ receptor agonists have been shown to induce the expression of c-fos in the dopamine-depleted striatum. This activation only occurs in the medium-sized $D_{1}$ GABAergic neurons that project directly back to the substantia nigra (Robertson et al., 1990). While $\mathrm{D}_{2}$ receptor agonists are unable to activate $\mathrm{c}-$ fos $(\mathrm{G}$. S. Robertson et al., 1989), recent experiments demonstrate that haloperidol, a $D_{2}$ receptor antagonist, rapidly and transiently induces c-fos mRNA in the striatum (Miller, 1990). Infusion of $D_{1}$ receptor agonists directly into the non-dopamine-depleted striatum has no effect on c-fos expression. Putatively, supersensitive dopamine receptors, as a result of dopamine depletion, are required for directly acting striatal c-fos induction (G. S. Robertson et al., 1989). On the other hand, experiments from this same group 

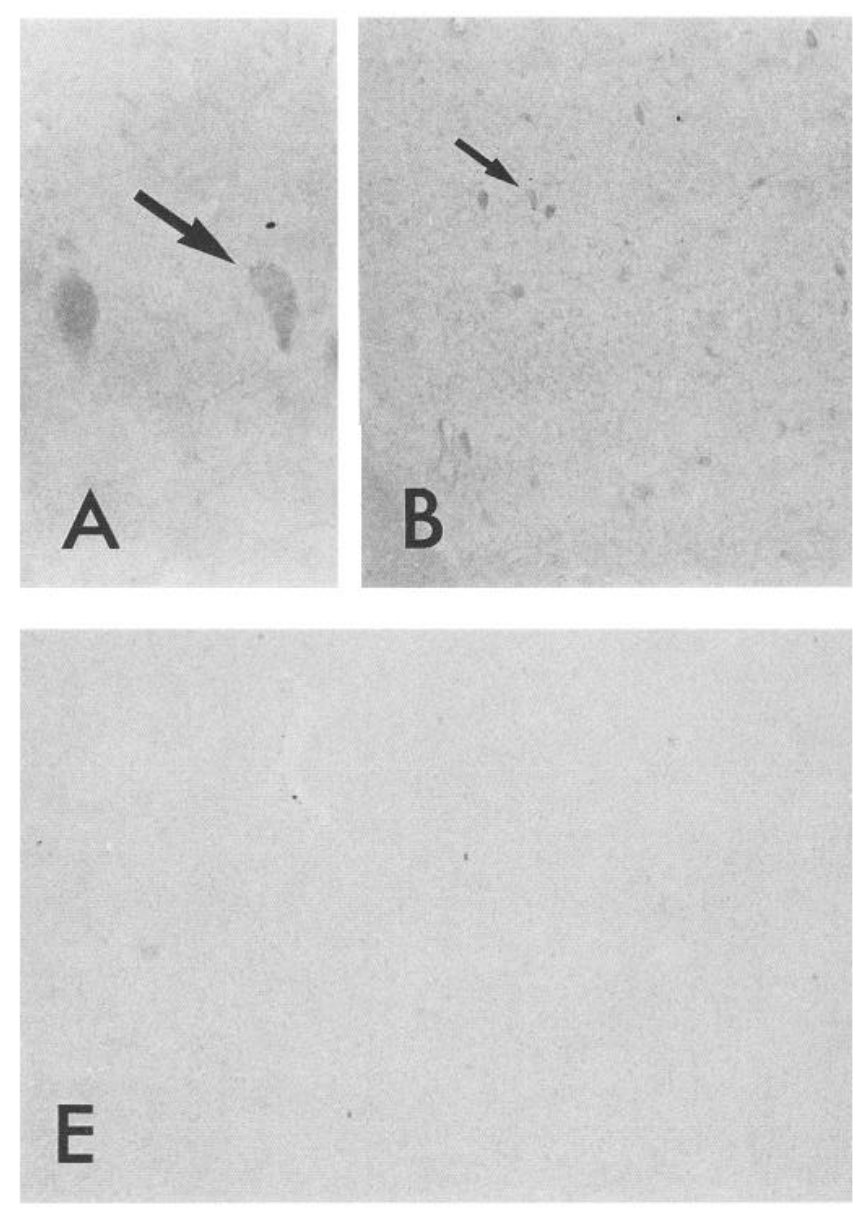
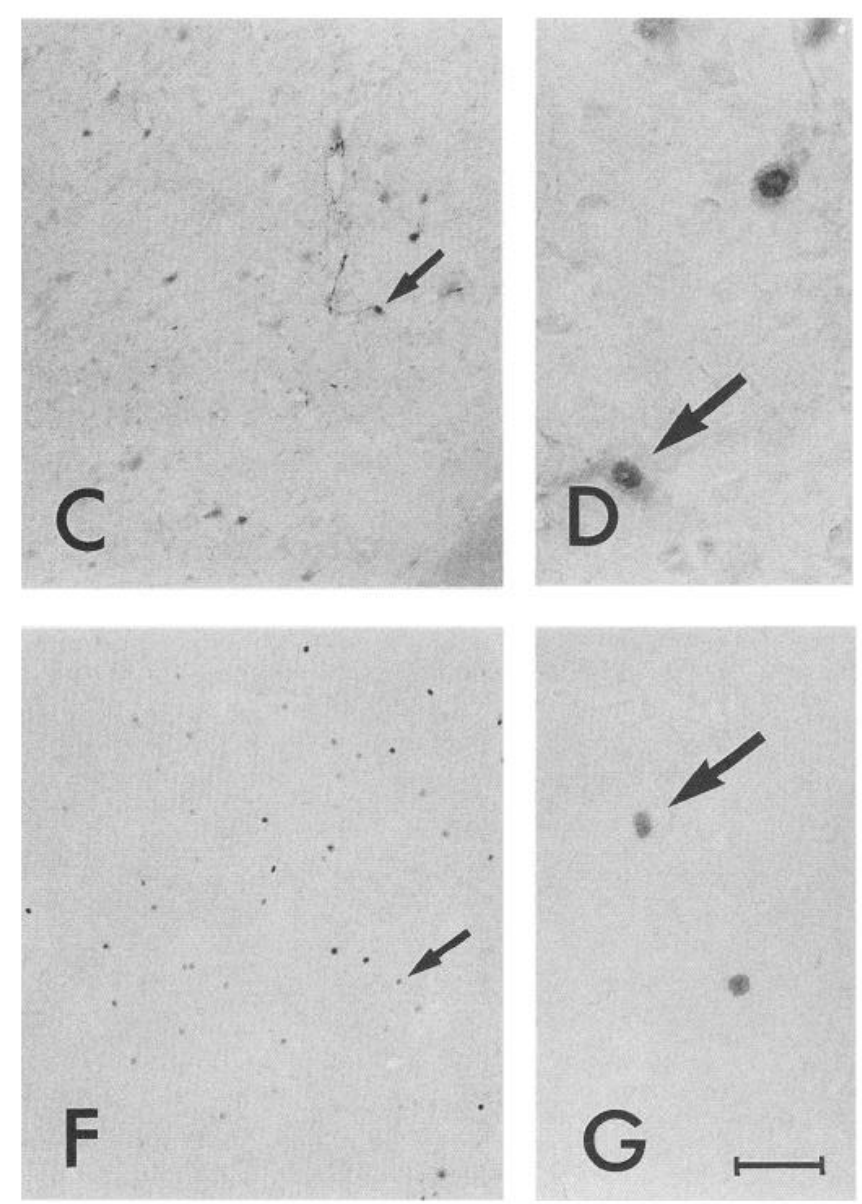

Figure 8. Fos immunoreactivity in the CS 1-3 hr after unilateral transection of the MFB. A, High-power bright-field photomicrograph of cells, putatively cholinergic, shown at low power in $B$ (arrow) demonstrating the basal levels of Fos staining in the CS contralateral to the lesion. $D$, High-power bright-field photomicrograph of the cells illustrated at low power in $C$ (arrow) demonstrating the robust nuclear induction of Fos protein on the side ipsilateral to the lesion $1 \mathrm{hr}$ after transection of the MFB. $E$, Bright-field photomicrograph of Fos immunoreactivity in small, putatively GABAergic, cells of the CS contralateral to the lesion $3 \mathrm{hr}$ after transection of the MFB. $F$, Low-power bright-field photomicrograph of Fos immunoreactivity in the ipsilateral CS $3 \mathrm{hr}$ after transection of the MFB. $G$, High-power photomicrograph of the cells demarcated by the arrow in $F$. Scale bar: $22 \mu \mathrm{m}$ for $A, D$, and $G ; 90 \mu \mathrm{m}$ for $B, C, E$, and $F$.

have demonstrated that the indirectly acting dopamine agonists, such as cocaine and $d$-amphetamine, are able to induce c-fos expression in an intact non-dopamine-depleted striatum as well as in a dopamine-depleted striatum (H. A. Robertson et al., 1989).

The time course of $\mathrm{c}-$ fos induction in GABAergic neurons of the CS following indirect agonists is similar to that observed in our transection model. It takes more than $2 \mathrm{hr}$ for an intraperitoneal injection of cocaine or $d$-amphetamine to induce Fos expression in the intact striatum (Graybiel et al., 1990), while the response to directly acting dopamine agonists occurs as quickly as $30 \mathrm{~min}$ postinjection (H. A. Robertson et al., 1989). Dopamine receptor antagonists, such as haloperidol, that act on $\mathrm{D}_{2}$ dopamine receptors present on cholinergic neurons, GABAergic/enkephalin neurons and presynaptic dopaminergic autoreceptors (Joyce and Marshall, 1987; Dawson et al., 1988) also activate c-fos expression in the medium-sized (GABAergic) neurons of the striatum (Dragunow et al., 1990). These authors suggest that it is unlikely that increased dopamine release following blockade of the dopamine autoreceptor is the cause of this c-fos induction because $\mathrm{D}_{1}$ antagonists did not prevent the
$\mathrm{D}_{2}$ antagonist-induced activation of c-fos (Dragunow et al., 1990). Furthermore, they suggest that there may be a tonic $\mathrm{D}_{2}$-mediated inhibition of c-fos expression in the striatum that is removed by the $\mathrm{D}_{2}$ antagonist.

The mechanism for the differential expression of $\mathrm{c}$-fos in the $\mathrm{CS}$ following MFB transection is perplexing. The acute effect of MFB transection on the release of dopamine in the CS is not known; however, the postsynaptic consequences may not be to the sudden withdrawal of dopamine. In fact, MFB transection may produce a burst of release of dopamine, followed by its abrupt withdrawal. Also, 6-OHDA lesions of the MFB produce an increased compensatory release of dopamine in the CS (Zhang et al., 1988). One hypothesis is that the burst of release of dopamine may be responsible for the induction of Fos in the GABAergic neurons and that this effect is mediated through the $D_{1}$ receptors. Fos induction in the cholinergic neurons is either the result of the sudden withdrawal of dopamine or a relatively faster acting and more transient $\mathrm{D}_{2}$ receptor-mediated response.

The data from the present experiments suggest that a specific temporal dopaminergic receptor activation is necessary to induce c-fos in the cholinergic neurons of the CS. The compen- 

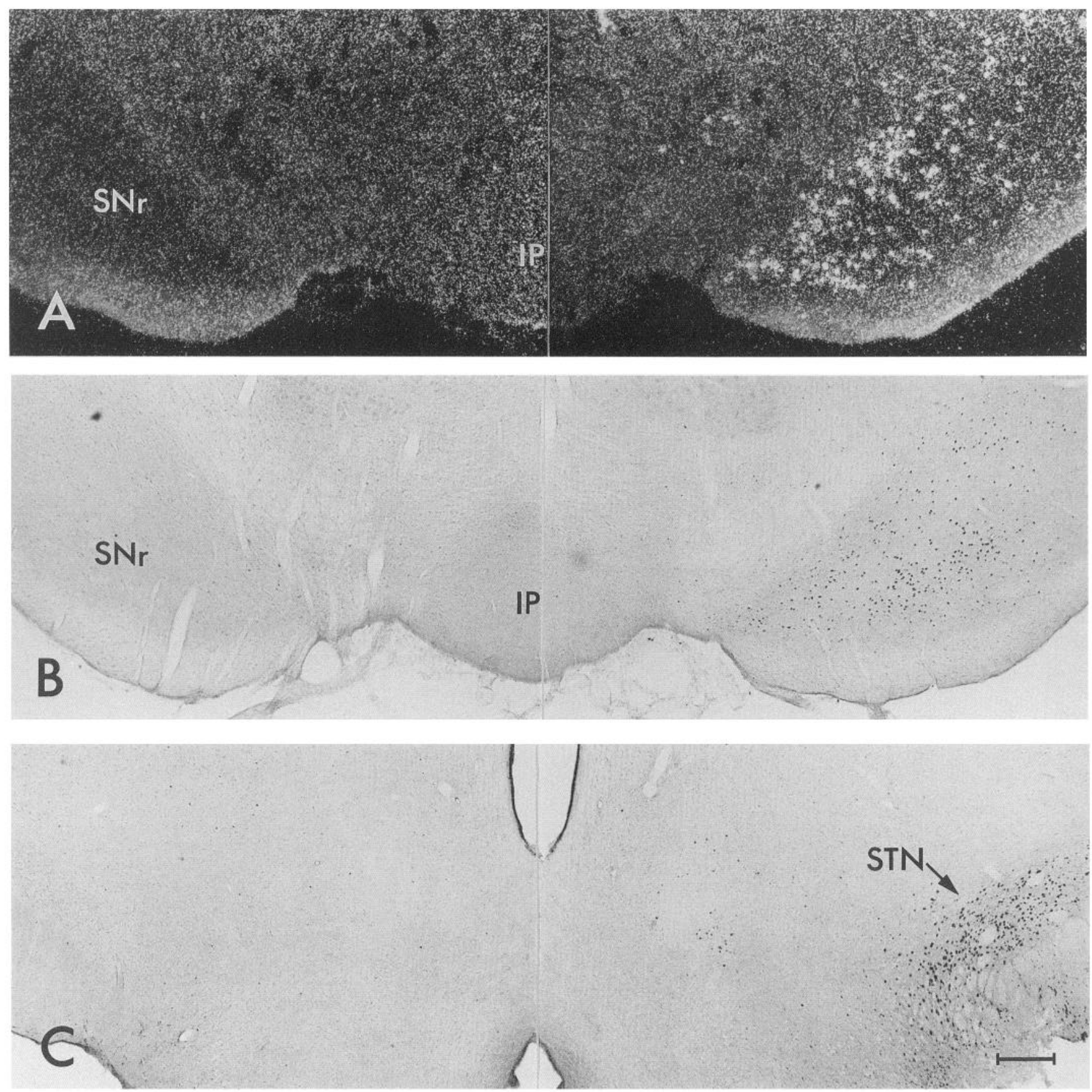

Figure 9. Fos immunohistochemistry and in situ hybridization in the $\mathrm{SNr}$ and the STN $6 \mathrm{hr}$ after unilateral transection of the MFB. A, Darkfield photomicrograph of the robust induction of $\mathrm{c}$-fos mRNA exhibited in the SNr ipsilateral to the lesion. $B$, Bright-field photomicrograph of the adjacent section to $A$ illustrating Fos immunoreactivity in the SNr. $C$, Bright-field photomicrograph demonstrating the large increase in Fos immunoreactivity in the STN ipsilateral to the lesion. $I P$, interpeduncular nucleus. Scale bar: $225 \mu \mathrm{m}$ for $A-C$.

satory changes effected by 6-OHDA lesions may prevent the "cholinergic" c-fos activation since it has been shown that 6-OHDA is capable of altering the expression of $D_{2}$ and $D_{1}$ receptor genes (Gerfen et al., 1990). Furthermore, both these experiments and those of other groups do not take into account the presence of other types of dopamine receptors reported in the striatum (Civelli, 1991).

Graybiel and colleagues also have shown that c-fos-positive neurons in the dopamine-depleted CS following acute cocaine and amphetamine treatment contain DARPP-32, a marker of the $D_{1}$ receptor, and that there is no c-fos response detectable in the GABA/enkephalin-containing neurons (Graybiel, 1991; Berretta et al., 1992). The GABA/enkephalin-containing neurons project through an interneuron in the GP to the STN forming one branch of the subthalamic loop (Gerfen, 1992). This loop is thought to be critical in the control of the basal ganglia outflow, and its overactivation may underlie some of the motor deficits in PD (Bergman et al., 1990; Graybiel, 1991). MFB 
transection at the level of the posterolateral hypothalamus deafferents SNr-projecting glutamatergic neurons in the STN. Assuming that the MFB lesion transects the GABAergic neurons in the GP that project to the STN, then it is plausible to speculate that the removal of this negative influence may be correlated with the hyperactivity and Fos induction in the STN through disinhibition. The present results also demonstrate that the transection of the GABAergic striatonigral pathway induces c-fos in the neurons of the SNr. One hypothesis is that the effect of dopamine at the $D_{2}$ receptor on GABAergic/enkephalin-containing neurons is inhibitory. Then, dopamine depletion, through either MFB transection, 6-OHDA, or perhaps in PD, would increase the GABA released from these neurons. Increased CS GABA release would inhibit GP projecting neurons to the STN, thus exciting STN neurons through disinhibition.

These results also suggest that the ability of a neuronal population to induce the c-fos gene may be related to that neuron's eventual fate. Interestingly, in some neuronal populations such as in the $\mathrm{SNc}$ there is no constitutive level of $\mathrm{c}-\mathrm{f}$ os expression. Upon axotomy $\mathrm{TH}$-containing neurons in the $\mathrm{SNc}$ never express either Fos immunoreactivity or c-fos mRNA and eventually die. TH-containing neurons in the LC upon axotomy possess a robust c-fos induction and do not die. The ability of the LC neurons to survive axotomy may be related to the presence of uninjured sustaining collaterals or the distance of the axotomy from the cell body (Reis and Ross, 1973; Ross et al., 1975; Reis et al., 1978).

It is of interest to note that not all GABAergic neurons in the $\mathrm{SNr}$ express a robust Fos response upon deafferentation. The data from our experiments suggest that the neurons that express higher levels of c-fos may be the ones that survive the injury. Recent studies have suggested the importance of feedforward neuronal degeneration that may be produced as a result of deafferenting lesions in reciprocally connected pathways such as the nigrostriatal system (Saji and Reis, 1987; Pasinetti et al., 1991). The delayed transneuronal cell death in the SNr, similar to that observed in the SNc, is protracted, taking up to $21 \mathrm{~d}$ to have its maximal effect (Saji and Reis, 1987).

Collectively, these data indicate that in contrast to previous reports on the disassociation of mRNA and protein following neuronal injury, (Nowak et al., 1990; Weiser et al., 1991, 1993) the longer-term alterations in the levels of expression of the TH gene products following axotomy of catecholamine neurons are correlated with $\mathrm{TH}$ activity. As expected the changes in the amounts of TH mRNA exceeded changes in TH activity. These data also suggest that expression of the immediate-early gene c-fos in a neuronal population may be correlated with cell survival following either axotomy or deafferentation. Whether Fos induction following injury is either a necessary mechanism of cell survival or merely a marker of increased neuronal activity requires further investigation.

\section{References}

Baker H (1990) Unilateral, neonatal olfactory deprivation alters tyrosine hydroxylase expression but not aromatic amino acid decarboxylase or GABA immunoreactivity. Neuroscience 36:761-771.

Bartel DP, Sheng M, Lau LF, Greenberg ME (1989) Growth factors and membrane depolarization activate distinct programs of early response gene expression: dissociation of Fos and Jun induction. Genes Dev 3:304-313.

Bergman H, Wichmann T, DeLong MR (1990) Reversal of experimental parkinsonism by lesions of the subthalamic nucleus. Science 249:1436-1438.
Bernhcimer H, Birkmayer W, Hornykiewicz O, Jellinger K, Seitelberser F (1973) Brain dopamine and the syndromes of Parkinson and Huntington: clinical, morphological and neurochemical correlations. J Neurol Sci 20:415-455.

Berretta S, Robertson HA, Graybiel AM (1992) Dopamine and glutamate agonists stimulate neuron-specific expression of Fos-like protein in the striatum. J Neurophysiol 68:767-777.

Calne DB, Zigmond MJ (1991) Compensatory mechanisms in degenerative neurologic diseases: insights from parkinsonism. Arch Neurol 48:361-363.

Ceccatelli S, Villar MJ, Goldstein M, Hokfelt T (1989) Expression of c-fos immunoreactivity in transmitter-characterized neurons after stress. Proc Natl Acad Sci USA 86:9569-9573.

Civelli O (1991) Molecular biology of the dopamine receptors. Eur J Pharmacol 207:277-286.

Coyle JT (1972) Tyrosine hydroxylase in rat brain-cofactor requirements, regional and subcellular distribution. Biochem Pharmacol 21: $1835-1844$.

Dawson VL, Dawson TM, Filloux FM, Wamsley JK (1988) Evidence for dopamine D-2 receptors on cholinergic interneurons in the rat caudate-putamen. Life Science 42:1933-1939.

Doucet JP, Squinto SP, Bazan NG (1990) Fos-Jun and the primary genomic response in the nervous system. Mol Neurobiol 4:27-55.

Dragunow M, Robertson HA (1987a) Generalized seizures induce c-fos protein in mammalian neurons. Neurosci Lett 82:157-161.

Dragunow M, Robertson HA (1987b) Kindling stimulation induces c-fos protein(s) in granule cells of the rat dentate gyrus. Nature 329: $441-442$.

Dragunow M, Robertson GS, Faull RLM (1990) Haloperidol induccs an accumulation of c-fos-like protein in rat striatal neurons: NMDA receptor mediation. Neuroscience 37:287-294.

Fass B, Butcher LL (1981) Evidence for a crossed nigrostriatal pathway in rats. Neurosci Lett 22:109-113.

Franza TM, Rauscher FR, Josephs SF, Curran T (1988) The Fos complex and Fos-related antigens recognize sequence elements that contain the AP-1 binding sites. Science 239:1150-1153.

Gerfen CR (1992) The neostriatal mosaic: multiple levels of compartmental organization. Trends Neurosci 15:133-139.

Gerfen CR, Engber TM, Mahan LC, Susel Z, Chase TN, Monsma FJ $\mathrm{Jr}$ (1990) D1 and D2 dopamine receptor-regulated gene expression of striatonigral and striatopallidal neurons. Science 250:1429-1432.

Gizang-Ginsberg E, Ziff EB (1990) Nerve growth factor regulates tyrosine hydroxylase gene transcription through a nucleoprotein complex that contains c-fos. Genes Dev 4:477-491.

Graybiel AM (1991) Immediate early gene activation in the striatum: new clue to function and plasticity in the basal ganglia? IBRO News 19:7.

Graybiel AM, Moratalla R, Robertson HA (1990) Amphetamine and cocaine induce drug-specific activation of the c-fos gene in striosomematrix and limbic subdivisions of the striatum. Proc Natl Acad Sci USA 87:6912-6916.

Greenberg ME, Greene LA, Ziff EB (1985) Nerve growth factor and epidermal growth factor induce rapid transient changes in proto-oncogene transcription in PC12 cells. J Biol Chem 260:14101-14110.

Herman JP, Lupp A, Abrous N, LeMoal M, Hertting G, Jackisch R (1988) Intrastriatal dopaminergic grafts restore inhibitory control over striatal cholinergic neurons. Exp Brain Res 73:236-248.

Hunt SP, Pini A, Evan G (1987) Induction of c-fos-like protein in spinal cord neurons following sensory stimulation. Nature $328: 632-$ 634.

Jackson D, Bruno JP, Stachowiak MK, Zigmond MJ (1988) Inhibition of striatal acetylcholine release by serotonin and dopamine after the intercerebral administration of 6-hydroxydopamine to neonatal rats. Brain Res 457:267-273.

Jones KJ, Evinger C (1991) Differential neuronal expression of c-fos proto-oncogene following peripheral nerve injury or chemically-induced seizure. J Neurosci Res 28:291-298.

Joyce JN (1991) Differential response of striatal dopamine and muscarinic cholinergic receptor subtypes to the loss of dopamine. I. Effects of intranigral or intracerebroventricular 6-hydroxydopamine lesions of the mesostriatal dopamine system. Exp Neurol 113:277-290.

Joyce JN, Marshall JF (1987) Quantitative autoradiography of dopamine D-2 sites in rat caudate-putamen: localization to intrinsic neurons and not to neocortical afferents. Neuroscience 20:773-795. Kubota Y, Inagaki S, Kito S, Wu JY (1987a) Dopaminergic axons 
directly make synapses with GABAergic neurons in the rat neostriatum. Brain Res 406:147-156.

Kubota Y, Inagaki S, Shimada S, Kito S, Eckenstein F, Tohyama M (1987b) Neostriatal cholinergic neurons receive direct synaptic inputs from dopaminergic axons. Brain Res 413:179-184.

Laughlin SE, Fallon JH (1982) Mesostriatal projections from the ventral tegmentum and dorsal raphe: cells project ipsilaterally or contralaterally but not bilaterally. Neurosci Lett 32:11-16.

Lloyd KD (1978) Neurotransmitter interaction related to central dopamine neurons. In: Essays in neurochemistry and neuropharmacology (Youdim MBH, Lovenberg W, Sharman DF, Lagnado JR, eds), pp 131-141. New York: Wiley.

Lowry OH, Rosebrough NJ, Farr AJ, Randall RJ (1951) Protein measurement with the folin phenol reagent. J Biol Chem 93:265-275.

Marshall JF, O'Dell SJ, Navarrete R, Rosenstein AJ (1990) Dopamine high-affinity transport site topography in rat brain: major differences between dorsal and ventral striatum. Neuroscience 37:11-21.

Miller JC (1990) Induction of c-fos mRNA expression in rat striatum by neuroleptic drugs. J Neurochem 54:1453-1455.

Morgan JI, Curran T (1989) Stimulus-transcription coupling in neurons: role of cellular immediate-early genes. Trends Neurosci 12:459 462.

Morgan JI, Cohen DR, Hempstead JL, Curran T (1987) Mapping patterns of c-fos expression in the central nervous system after seizure. Science 237:192-197.

Mugnaini E, Oertel WH (1985) An atlas of the distribution of GABAergic neurons and terminals in the rat CNS as revealed by GAD immunohistochemistry. In: Handbook of chemical neuroanatomy. GABA and neuropeptides in the CNS (Bjorklund A, Hokfelt T, Kuhar MJ, eds), pp 436-622. New York: Elsevier.

Nowak TS Jr, Ikeda J, Nakajima T (1990) 70-kDa heat shock protein and c-fos gene expression after transient ischemia. Stroke 21:107111.

Pasinetti GM, Lerner SP, Johnson SA, Morgan DG, Telford NA, Finch CE (1989) Chronic lesions differentially decrease tyrosine hydroxylase messenger RNA in dopaminergic neurons of the substantia nigra. Mol Brain Res 5:203-209.

Pasinetti GM, Morgan DG, Finch CE (1991) Disappearance of GADmRNA and tyrosine hydroxylase in substantia nigra following striatal ibotenic acid lesions: evidence for transneuronal regression. Exp Neurol 112:131-139.

Pasinetti GM, Osterburg HH, Kelly AB, Kohama S, Morgan DG, Reinhard JF Jr, Stellwagen RH, Finch CE (1992) Slow changes of tyrosine hydroxylase gene expression in dopaminergic brain neurons after neurotoxin lesioning: a model for neuron aging. Mol Brain Res 13:6373.

Reis DJ, Ross RA (1973) Dynamic changes in dopamine- $\beta$-hydroxylase activity during the anterograde and retrograde reaction to injury of central noradrenergic axons. Brain Res 57:307-326.

Reis DJ, Gilad G, Pickel VM, Joh TH (1978) Reversible changes in the activities and amounts of tyrosine hydroxylase in dopamine neurons of the substantia nigra in response to axonal injury as studied by immunochemical and immunocytochemical methods. Brain Res 144:325-342.

Ribak CE, Vaughn JE, Roberts E (1979) The GABA neurons and their axon terminals in rat corpus striatum as demonstrated by GAD immunocytochemistry. J Comp Neurol 187:261-283.

Robertson GS, Herrera DG, Dragunow M (1989a) L-Dopa activates c-fos expression in the striatum of 6-hydroxydopamine-lesioned rats. Eur J Pharmacol 159:99-100.

Robertson GS, Vincent SR, Fibiger HC (1990) Striatonigral projection neurons contain Dl dopamine receptor-activated c-fos. Brain Res 523:288-290.

Robertson HA, Peterson MR, Murphy K (1989b) D1 dopamine receptor agonists selectively activate striatal c-fos independent of rotational behavior. Brain Res 503:346-349.

Robertson HA, Paul ML, Moratalla R, Graybiel AM (1991) Expression of the immediate early gene c-fos in basal ganglia: induction by dopaminergic drugs. Can J Neurol Sci 18:380-383.

Ross RA, Joh TH, Reis DJ (1975) Reversible changes in the accumulation and activities of tyrosine hydroxylase and dopamine $\beta$-hydroxylase in neurons of nucleus locus ceruleus during the retrograde reaction. Brain Res 92:57-72.

Saji M, Reis DJ (1987) Delayed transneuronal death of substantia nigra neurons prevented by gamma-aminobutyric acid agonist. Science 235:66-69.

Scatton B (1982) Further evidence for the involvement of D2, but not D1 dopamine receptors in dopaminergic control of striatal cholinergic transmission. Life Science 31:2883-2890.

Segovia J, Tillakaratne NJK, Whelan K, Tobin AJ, Gale K (1990) Parallel increases in striatal glutamic acid decarboxylase activity and GAD mRNA levels in rats with lesions of the nigrostriatal pathway. Brain Res 529:345-348.

Segovia J, Armstrong DM, Benzing WC, Hornby PJ (1991) Striatal glutamic acid decarboxylase immunoreactivity after dopaminergic deafferentation: densitometric analysis. Neurosci Lett 122:252-256.

Sheng M, Greenberg ME (1990) The regulation and function of c-fos and other immediate early genes in the nervous system. Neuron 4:477485.

Vincent SR, Nagy JL, Fibiger HC (1978) Increased striatal glutamic acid decarboxylase after lesions of the nigro-striatal pathway. Brain Res 143:168-173.

Weiser M, Baker H, Wessel TC, Joh TH (1991) Early molecular responses to axotomy and deafferentation: cholinergic neurons. Soc Neurosci Abstr 17:561.

Weiser M, Baker H, Wessel TC, Joh TH (1993) Axotomy-induced differential gene induction in neurons of the locus ceruleus and substantia nigra. Mol Brain Res 17:319-327.

Zhang WQ, Tilson HA, Nanry KP, Hong JS, Stachowiak MK (1988) Increased dopamine release from striata of rats after unilateral nigrostriatal bundle damage. Brain Res 461:335-342.

Zigmond MJ, Abercrombie ED, Berger TW, Grace AA, Stricker EM (1990) Compensations after lesions of central dopaminergic neurons: some clinical and basic implications. Trends Neurosci 13:290-296. 